\title{
World Distribution, Population Genetics, and Health Burden of the Hemoglobinopathies
}

\author{
Thomas N. Williams ${ }^{1}$ and David J. Weatherall ${ }^{2}$ \\ ${ }^{1}$ Kenya Medical Research Institute/Wellcome Trust Programme, Centre for Geographical Research, \\ Kilifi District Hospital, PO Box 230, Kilifi, Kenya \\ ${ }^{2}$ Weatherall Institute of Molecular Medicine, University of Oxford, John Radcliffe Hospital, \\ Oxford OX39DU, United Kingdom \\ Correspondence: twilliams@kilifi.kemri-wellcome.org
}

\begin{abstract}
Although information about the precise world distribution and frequency of the inherited hemoglobin disorders is still limited, there is no doubt that they are going to pose an increasing burden on global health resources in the future. Their high frequency is a reflection of natural selection combined with a high frequency of consanguineous marriages in many countries, together with an epidemiological transition; whereby, as public health measures improve in the poorer countries of the world, more babies with these disorders are surviving to present for treatment.
\end{abstract}

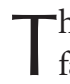
he inherited disorders of hemoglobin are by far the most common monogenic diseases. Recent surveys suggest that between 300,000 and 400,000 babies are born with a serious hemoglobin disorder each year and that up to $90 \%$ of these births occur in low- or middle-income countries (Christianson et al. 2006). Here we will discuss the world distribution of these conditions and what is known about the mechanisms that have led to their extremely high frequency in many tropical countries.

\section{DISTRIBUTION AND FREQUENCY OF THE HEMOGLOBIN DISORDERS}

An estimate of the annual births of the important hemoglobin disorders is shown in Table 1. These figures are only a very approximate assessment and are based, in many cases, on only relatively small samples from localized regions of different countries. It has been found recently that the distribution of all the important hemoglobin disorders is extremely heterogeneous within different countries, even within small geographical distances (Weatherall 2010). Hence, a great deal more work needs to be done to provide anything like an accurate estimate of their true frequency.

Maps showing the world distribution of the sickle cell disorders, hemoglobin $(\mathrm{Hb}) \mathrm{E}$ and the different forms of thalassemia are shown in Figures 1 and 2. Sickle cell anemia occurs throughout sub-Saharan Africa and in small pockets in the Mediterranean region, the Middle East, and the Indian subcontinent. By the use of haplotype analysis, that is the pattern of single nucleotide polymorphisms in the $\beta$-globin gene cluster, it has been determined that the sickle cell

Editors: David Weatherall, Alan N. Schechter, and David G. Nathan

Additional Perspectives on Hemoglobin and Its Diseases available at www.perspectivesinmedicine.org

Copyright (C) 2012 Cold Spring Harbor Laboratory Press; all rights reserved; doi: 10.1101/cshperspect.a011692

Cite this article as Cold Spring Harb Perspect Med 2012;2:a011692 
T.N. Williams and D.J. Weatherall

Table 1. A breakdown of the annual number of births with the different hemoglobin disorders

\begin{tabular}{lr}
\hline Annual births with major hemoglobin disorders \\
\hline$\beta$-thalassemia major & 22,989 \\
HbE $\beta$ thalassemia & 19,128 \\
HbH disease & 9568 \\
Hb Bart's hydrops $\left(\alpha^{0} / \alpha^{0}\right)$ & 5183 \\
SS disease & 217,331 \\
S $\beta$ thalassemia & 11,074 \\
SC disease & 54,736 \\
\hline
\end{tabular}

From available data (Modell and Darlison 2008; Weatherall 2010).

gene arose at least twice, once in Africa and once in India or the Middle East (Kulozik et al. 1986). Similar evidence suggests that the gene may have also arisen on several different occasions in sub-Saharan Africa although these data have to be reviewed with caution because it is possible that the different haplotype patterns could have resulted from gene conversion events (Flint et al. 1998). Hemoglobin SC disease is more restricted to parts of west and north Africa whereas $\mathrm{HbS} \beta$ thalassemia occurs in localized parts of sub-Saharan Africa and sporadically throughout the Middle East and Indian subcontinent. Unlike some forms of $\alpha$ thalassemia and $\mathrm{HbE}$, which are discussed below, the gene fre- quency for HbS rarely rises much above $20 \%-$ $25 \%$ of a particular population although there are occasional exceptions.

Hemoglobin E, the other particularly common structural hemoglobin variant, occurs widely throughout the eastern half of the Indian subcontinent, Bangladesh, Myanmar, and east and southeast Asia. It occurs at varying frequencies but in some parts of Asia, notably the northern parts of Thailand and Cambodia, called the "hemoglobin E triangle," up to 70\% of the population are carriers (see Fucharoen and Weatherall 2012).

The mild forms of $\alpha$ thalassemia (see Higgs 2012), which result from a single $\alpha$ gene deletion $(-\alpha / \alpha \alpha)$, occur in a broad tropical belt stretching from sub-Saharan Africa through the Mediterranean regions and Middle East to the Indian subcontinent and the whole of east and southeast Asia. In this band, they occur at a frequency of $10 \%-25 \%$, although in a few localized populations such as those of north India and Papua New Guinea, they are found in up to $80 \%$ of the population and the gene appears to be going to fixation. The more severe forms of $\alpha$ thalassemia due to loss of both $\alpha$ chain genes$\alpha^{0}$ thalassemia $(-/ \alpha \alpha)$ - have a much more restricted occurrence, reaching high frequencies

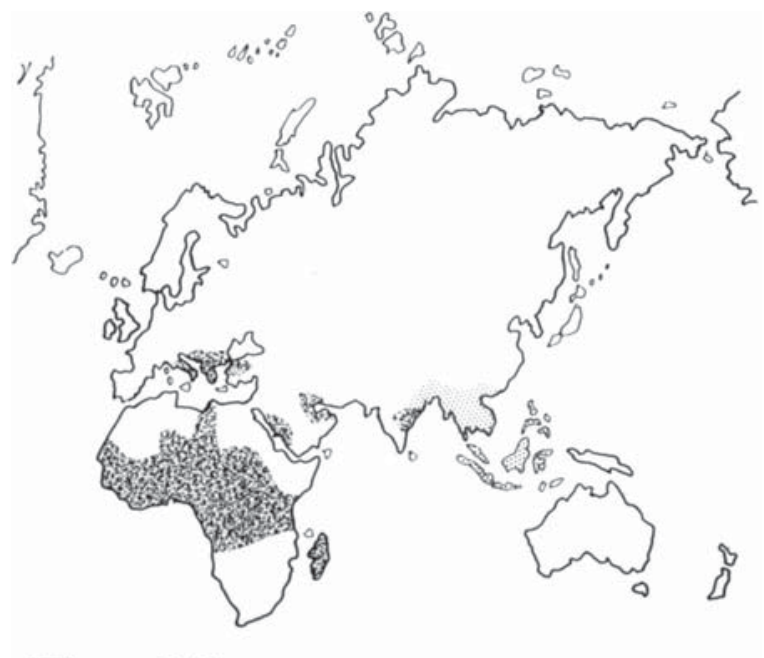

$\mathrm{HbE}$ HbS

Figure 1. The world distribution of the origins of hemoglobin S and hemoglobin E. (From Weatherall and Clegg 2001; reprinted, with permission, from the author.) 


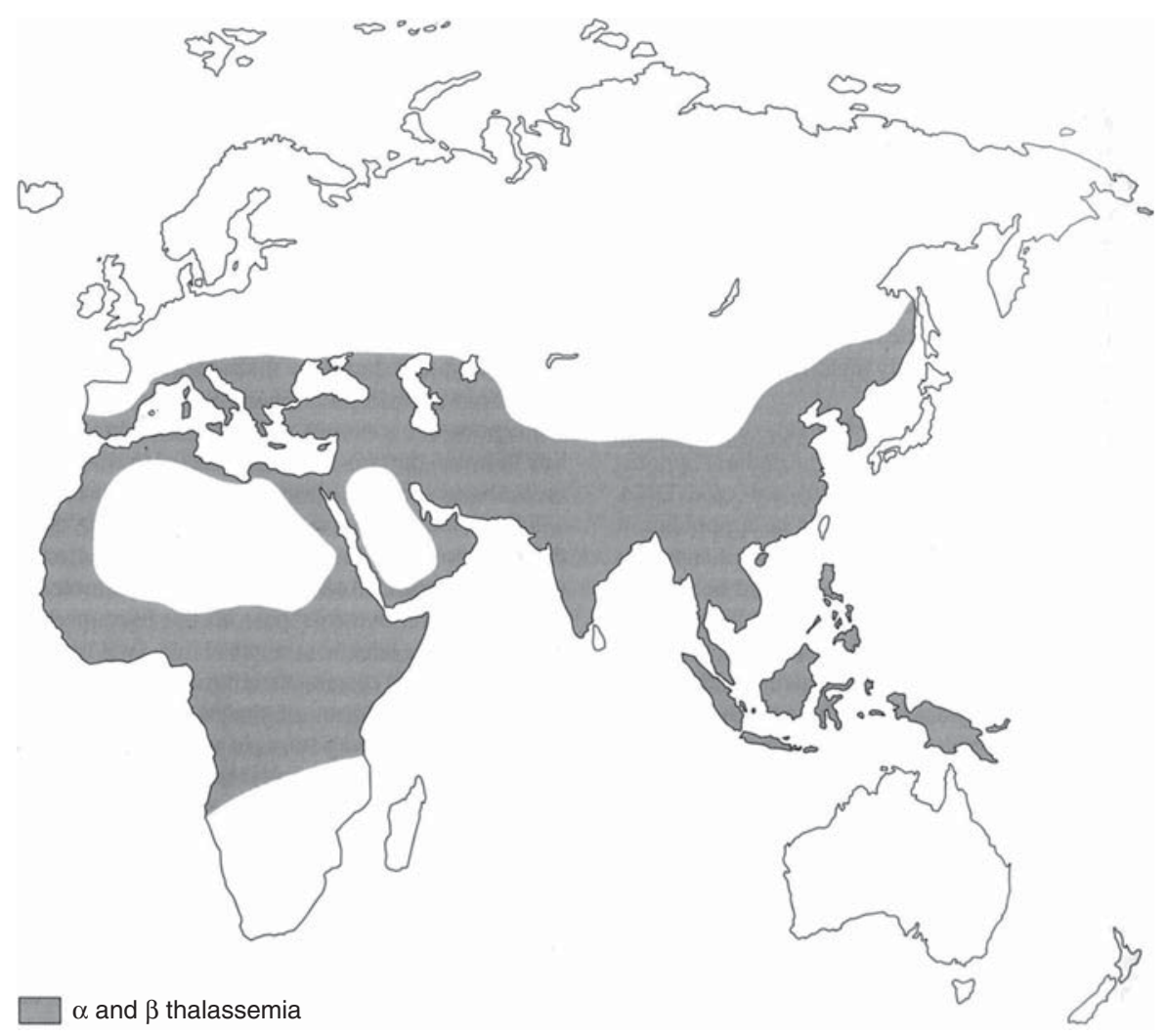

Figure 2. The world distribution of the origins of the $\alpha$ and $\beta$ thalassemias. (From Weatherall and Clegg 2001; reprinted, with permission, from the author.)

only in southeast Asia and in some of the Mediterranean islands. They occur sporadically throughout other populations, however, although their true frequency has not been determined.

Although the hemoglobinopathies all occur at particularly high frequencies in these tropical regions, they have been transported to most countries of the world by population migrations over many years. For example, the sickle cell gene is extremely common in many of the Caribbean Islands and in parts of North America, and occurs in most countries to a varying degree. The same phenomenon has occurred in the case of all the common forms of thalassemia. Interestingly, there are no common hemoglobin disorders among the American Indian population, probably because these conditions were not established in Asia at the time of the early population movements across the Bering Strait.

\section{WHY ARE THE INHERITED DISORDERS OF HEMOGLOBIN SO COMMON?}

There are several reasons why the hemoglobin disorders have reached such extraordinarily high gene frequencies in many tropical countries. First and foremost, it appears that their frequency reflects natural selection through protection of heterozygotes against severe malaria, a mechanism first suggested by Haldane (1949) and later confirmed independently in the case of sickle cell anemia by Allison (1954a,b,c). We will consider the possible mechanisms later in this work.

Natural selection is not the only mechanism involved in maintaining these high gene 
frequencies. Another important factor is the relatively high frequency of consanguineous marriages in many of the high frequency countries; this mechanism has an important effect on increasing the gene frequency of any recessively inherited disorder. Although accurate data on the frequency of consanguineous marriage are lacking, there is no doubt from such that are available that this is an important factor in helping to maintain the global health problem posed by these conditions. Another important factor is the epidemiological transition, whereby as public health and nutritional standards improve in the poorer countries, babies with these conditions who would otherwise have died in early life are now living long enough to present for diagnosis and management. As evidenced by what happened in Cyprus after it went through this transition after the Second World War, there is no doubt that this mechanism will cause a major increase in the number of patients with the more severe hemoglobin disorders in the future (Weatherall and Clegg 2001). Finally, the varying distribution of some of the hemoglobin disorders in different populations reflects strong founder effects by their original inhabitants. This mechanism is clearly illustrated in some of the Pacific Island populations (O'Shaughnessy et al. 1990).

It should be emphasized that even if some of the selective factors are reduced-the eradication of malaria, for example-it will take many generations before the frequency of these diseases starts to decline; a period during which there will be a tendency for their increase because of the epidemiological transition outlined above.

\section{NATURAL SELECTION AND THE HEMOGLOBIN DISORDERS}

During the six decades since Haldane first proposed the malaria hypothesis (Haldane 1949), evidence has steadily grown to confirm that malaria is indeed the primary force behind the high frequency of inherited hemoglobin disorders that is seen in many tropical and subtropical populations. The evidence supporting this assertion comes from four main sources: the sim- ilarity between the distributions of malaria and specific hemoglobin disorders at local, regional, and global scales; from population genetic predictions of their historic age; from clinical studies conducted in malaria-endemic areas; and from mechanistic studies conducted both in-vitro and ex-vivo. Although such evidence is strongest for $\mathrm{HbS}$ and for the $\alpha$ thalassemias, which have been the focus of the most research, there can now be little doubt that malaria is responsible for the current distributions of all the major hemoglobin disorders. In the following sections we will review the evidence as it stands for each hemoglobin disorder individually. The proposed mechanisms for malaria protection by these conditions are summarized in Table 2. However, later in this work we will also discuss emerging data that suggest that selection for hemoglobin disorders may be competitive, and might be influenced by negative effects when inherited in combination with one another.

\section{Hemoglobin S}

The heterozygous state for hemoglobin S (HbAS) is the best described of all malaria-protective traits and is used as the classic example of balanced polymorphism in schools and colleges throughout the world. The close resemblance between the geographic distribution of HbAS and that of malaria, documented by a number of different investigators more than 60 years ago (Beet 1946, 1947; Brain 1952; Foy et al. 1952, 1954), gave the first clues. But it is Allison who first articulated the malaria hypothesis with regard to $\mathrm{HbS}$ most definitively (Allison 1954a,b,c). Not only, as others before him (Beet 1946, 1947; Brain 1952), did he note that "sicklers" were significantly less likely than "non-sicklers" to carry malaria parasites under conditions of natural exposure but he also showed that, when inoculated intravenously with large volumes of parasite-infected blood, sicklers were less likely to develop a clinical malaria infection. Many studies have since been conducted that put the malaria hypothesis with regard to HbS beyond reasonable doubt. First, the close correspondence between the frequencies of the $\beta^{s}$ allele and the historic prevalence of malaria 
Epidemiology of the Hemoglobinopathies

Table 2. Summary of some proposed mechanisms of action of the malaria-resistance polymorphisms involving the inherited hemoglobin disorders

\begin{tabular}{|c|c|c|}
\hline $\begin{array}{l}\text { Hemoglobin } \\
\text { disorder }\end{array}$ & $\begin{array}{l}\text { Potential mechanisms for } \\
\text { malaria protection }\end{array}$ & Key references \\
\hline \multirow[t]{4}{*}{$\begin{array}{l}\text { Sickle cell trait } \\
\quad(\mathrm{HbAS})\end{array}$} & $\begin{array}{l}\text { Impairment of } P \text {. falciparum red cell } \\
\text { invasion and growth under conditions of } \\
\text { low oxygen tension }\end{array}$ & $\begin{array}{l}\text { Friedman 1978; Pasvol et al. 1978; Friedman } \\
\text { et al. } 1979\end{array}$ \\
\hline & $\begin{array}{l}\text { Enhanced removal of parasite-infected } \\
\text { HbAS red blood cells }\end{array}$ & $\begin{array}{l}\text { Luzzatto et al. 1970; Friedman 1978; Roth } \\
\text { et al. 1978; Shear et al. 1993; Ayi et al. } 2004\end{array}$ \\
\hline & $\begin{array}{l}\text { Reduced pathogenicity of } P \text {. falciparum } \\
\text { infected red blood cells because of } \\
\text { reduced expression of PfEMP1 }\end{array}$ & Cholera et al. 2008; Cyrklaff et al. 2011 \\
\hline & $\begin{array}{l}\text { Improved acquisition of malaria-specific } \\
\text { immunity }\end{array}$ & $\begin{array}{l}\text { Edozien et al. 1960; Cornille-Brogger et al. } \\
\text { 1979; Guggenmoos-Holzmann et al. } \\
\text { 1981; Marsh et al. 1989; Bayoumi et al. } \\
\text { 1990; Abu-Zeid et al. 1992; Odegbemi } \\
\text { and Williams 1995; Le Hesran et al. 1999; } \\
\text { Cabrera et al. 2005; Williams et al. 2005a; } \\
\text { Verra et al. 2007b }\end{array}$ \\
\hline \multirow[t]{3}{*}{$\begin{array}{l}\text { Hemoglobin C } \\
\text { (HbAC and } \\
\text { HbCC) }\end{array}$} & $\begin{array}{l}\text { Impairment of } P \text {. falciparum red cell } \\
\text { invasion and growth under conditions of } \\
\text { low oxygen tension }\end{array}$ & $\begin{array}{l}\text { Friedman et al. 1979; Pasvol and Wilson } \\
\text { 1982; Olson and Nagel 1986; Fairhurst } \\
\text { et al. } 2003\end{array}$ \\
\hline & $\begin{array}{l}\text { Improved acquisition of malaria-specific } \\
\text { immunity }\end{array}$ & Ringelhann et al. 1976; Verra et al. 2007b \\
\hline & $\begin{array}{l}\text { Reduced pathogenicity of P. falciparum } \\
\text { infected red blood cells because of } \\
\text { reduced expression of PfEMP1 }\end{array}$ & $\begin{array}{l}\text { Fairhurst et al. 2005; Brittain et al. 2007; } \\
\text { Cyrklaff et al. } 2011\end{array}$ \\
\hline $\begin{array}{l}\text { Hemoglobin E } \\
\text { (HbAE and } \\
\text { HbEE) }\end{array}$ & $\begin{array}{l}\text { Impairment of } P \text {. falciparum red cell } \\
\text { invasion and growth }\end{array}$ & Chotivanich et al. 2002 \\
\hline \multirow[t]{3}{*}{$\alpha$ thalassemia } & $\begin{array}{l}\text { Specific protection against malaria-induced } \\
\text { anaemia }\end{array}$ & $\begin{array}{l}\text { Allen et al. 1997; Williams et al. 2005d; } \\
\text { Wambua et al. 2006; May et al. 2007; } \\
\text { Fowkes et al. 2008; Veenemans et al. } 2008\end{array}$ \\
\hline & $\begin{array}{l}\text { Reduced pathogenicity through reduced } \\
\text { cytoadherence or rosetting }\end{array}$ & $\begin{array}{l}\text { Udomsangpetch et al. 1993; Carlson et al. } \\
\text { 1994; Cockburn et al. } 2004\end{array}$ \\
\hline & $\begin{array}{l}\text { Immuological priming through cross- } \\
\text { species immunity between } P \text {. vivax } \\
\text { and } P \text {. falciparum }\end{array}$ & Williams et al. 1996; Veenemans et al. 2011 \\
\hline \multirow[t]{3}{*}{$\beta$ thalassemia } & $\begin{array}{l}\text { Enhanced removal of parasite-infected } \\
\text { red blood cells }\end{array}$ & Ayi et al. 2004 \\
\hline & $\begin{array}{l}\text { Reduced invasion and growth of } \\
\quad \text { P. falciparum parasites }\end{array}$ & Kaminsky et al. 1986; Senok et al. 1997 \\
\hline & $\begin{array}{l}\text { Reduced pathogenicity through reduced } \\
\text { cytoadherence or rosetting }\end{array}$ & $\begin{array}{l}\text { Udomsangpetch et al. 1993; Carlson et al. } \\
1994\end{array}$ \\
\hline
\end{tabular}

has been confirmed through a growing number of surveys at both the local (Enevold et al. 2007) and global scales (Livingstone 1973, 1985; Cavalli-Sforza et al. 1994). Recently, this relationship has been quantified statistically, an analysis that found strong geographical support for the malaria hypothesis in Africa but not in either the Americas or in Asia (Piel et al. 2010). Hemoglobin $S$ is absent from indigenous populations in the Americas, probably because malaria did not reach the continent until relatively recently, whereas in Asia it follows a rather 
restricted distribution, being confined to a small number of tribal populations in India (Piel et al. 2010).

Direct clinical support for a protective effect of HbAS has been provided by case control, cohort, and family-based association studies conducted in multiple populations over the last 30 years (for summary, see Williams et al. 2005b; Jallow et al. 2009). In general, such studies have shown that $\mathrm{HbAS}$ is $\sim 50 \%$ protective against uncomplicated and $>80 \%$ protective against severe $P$. falciparum malaria. Although few individual studies have been powered to detect an effect on malaria-specific mortality, HbAS was associated with $55 \%$ protection against all-cause mortality in children 6-16 months old in a single cohort study conducted in Western Kenya (Aidoo et al. 2002). Intriguingly, HbAS has also been associated with protection against invasive bacterial infections in two studies conducted in different parts of Africa (Eeckels et al. 1967; Scott et al. 2011). This observation appears to be explained by the protective effect of HbAS against malaria and provides evidence for a causal association between malaria and bacterial infections, indicating that in malaria-endemic environments, genetic factors like HbAS may confer an additional benefit of protection against death from bacterial diseases (Scott et al. 2011). Recently, Gouagna and colleagues working in Burkina Faso, made an additional intriguing observation regarding the malaria-protective effect of $\mathrm{HbS}$ (Gouagna et al. 2010). Although HbAS protects against clinical malaria infections, parasite-infected blood from HbAS subjects is several times more infectious to the Anopheles vector than that of normal subjects (Gouagna et al. 2010). This observation, which is echoed by a similar observation from Senegal (Lawaly et al. 2010), suggests that the personal advantage of HbAS is not only balanced by the cost of potential homozygosity in offspring but also by that of increased malaria transmission to the general population.

Whereas the malaria-protective effect of HbAS is clear, the effect of the homozygous state, HbSS, on malaria risk is more controversial. Biologically, there are hypothetical reasons why subjects with HbSS might either enjoy a greater degree of protection than those with HbAS or, conversely, might be at more increased risk than normal subjects (Williams and Obaro 2011). Few controlled studies of this question have been reported but the balance of evidence suggests that both scenarios might be true. Subjects with HbSS appear to be less susceptible than normals to developing malaria infections (Makani et al. 2010; McAuley et al. 2010) but are highly susceptible to the catastrophic consequences of malaria, particularly severe anemia, if they do become infected with the disease (Makani et al. 2010; McAuley et al. 2010; Williams and Obaro 2011). The net result is that malaria is almost certainly a major cause of premature mortality in children born with HbSS in malaria-endemic areas and that the early detection of HbSS in association with active malaria prevention could have a major impact on survival (Serjeant 2005).

\section{The Mechanism of Malaria Protection Afforded by HbAS}

Although the fact that HbAS confers malaria protection is now well established, the mechanism by which it does so remains a matter of some speculation. Through early studies, conducted soon after it became possible to grow malaria parasites in culture, investigators converged on the general hypothesis that protection resulted from impairment in the invasion and growth of $P$. falciparum parasites into HbAS red cells under conditions of low oxygen tension that were physiologically representative of in vivo conditions (Friedman 1978; Pasvol et al. 1978; Friedman et al. 1979). However, a number of alternative hypotheses have subsequently developed. Several investigators have suggested that the mechanism may relate to the enhanced removal of parasite-infected HbAS red blood cells. Some have proposed that this may relate to the fact that such cells sickle under low oxygen tension (Luzzatto et al. 1970; Friedman 1978; Roth et al. 1978) and that this leads to their premature destruction in the spleen (Friedman 1978; Shear et al. 1993), whereas Ayi and colleagues have proposed a mechanism that is generic to a number of red cell disorders 
Epidemiology of the Hemoglobinopathies

and involves the enhanced opsonization of red cells infected with ring-stage parasites through a process that involves increased oxidative stress (Ayi et al. 2004).

An alternative hypothesis has emerged more recently. Cholera and colleagues have shown that in vitro, relative to parasitized normal HbAA red blood cells, the binding of parasitized HbAS red blood cells to both microvascular endothelial cells and to blood monocytes was significantly reduced and that this correlated with altered surface display of the parasite-encoded protein P. falciparum Erythrocyte Protein-1 (PfEMP1) (Cholera et al. 2008). Because the PfEMP1-mediated sequestration of mature parasites in the post-capillary venules of critical tissues such as the brain have been implicated in both the pathogenesis of severe malaria and the evasion of parasite-infected red cells from immune clearance by the spleen, this provides an attractive explanation for the protective effect of HbAS. Very recently, Cyrklaff and colleagues have elaborated on this hypothesis by showing, again in vitro, that HbAS affects the trafficking system that directs PfEMP1 to the surface of infected erythrocytes. Using cryo-electron tomography they showed that within the cytoplasm of normal red blood cells the parasite proteins are transported to the surface via a parasite-generated host-derived actin cytoskeleton but that hemoglobin oxidation products disrupted this process in HbAS red cells (Cyrklaff et al. 2011).

Whereas all the hypotheses discussed so far imply that HbAS protects against malaria entirely through innate mechanisms, data from both epidemiological and clinical studies suggest that this may not be the entire story. The protective effect of HbAS in naturally exposed populations increases with age (Cornille-Brogger et al. 1979; Guggenmoos-Holzmann et al. 1981; Le Hesran et al. 1999; Williams et al. 2005a), indicating that the mechanism might not be entirely innate but might also include an acquired, immunological component. This hypothesis is supported by a number of studies that have reported enhanced malaria-specific immune responses in HbAS individuals (Edozien et al. 1960; Marsh et al. 1989; Bayoumi et al. 1990; Abu-Zeid et al. 1992; Odegbemi and
Williams 1995; Cabrera et al. 2005; Verra et al. 2007a), and potentially by recent studies using a mouse model that suggest an immuno-modulatory mechanism mediated through hemoxygenase-1 (Ferreira et al. 2011). However, the mouse model of the sickling disorders is metabolically very different to the human sickle-cell traits. Furthermore, whereas such studies appear to support an immune component to the malaria protective effects of HbAS they are balanced by others that show no apparent differences between $\mathrm{HbAS}$ and normal subjects with regard to a range of immunological responses (CornilleBrogger et al. 1979; Storey et al. 1979; Le Hesran et al. 1999; Tan et al. 2011), leaving the balance between innate and acquired mechanisms unresolved.

From the above discussion, it is clear that HbAS is associated with strong protection against all forms of clinical $P$. falciparum malaria but that the mechanism for this protection remains somewhat speculative. Although many plausible mechanisms have been proposed during the last 40 years, which (if any) provides the true explanation remains unresolved. One possibility is that there is no single mechanism for the protective effect of HbAS but that protection results from the composite of many of the mechanisms described or by different mechanisms in different populations; more work will be required, both in vitro and ex vivo, to resolve this question definitively.

\section{Hemoglobin C}

Fewer studies have focused on the malaria-protective effects of $\mathrm{HbC}$ than for HbS. The geographic range of $\mathrm{HbC}$ is considerably more limited than that of $\mathrm{HbS}$, being centered on West and North-West Africa with the exception of a low-frequency corridor between West Africa and Egypt that appears to reflect patterns of human migration (FB Piel, AP Patil, RE Howes, et al., unpubl.). Although historically $\mathrm{HbC}$ has been restricted to malaria-endemic communities, to the best of our knowledge the relationship between the population frequency of $\mathrm{HbC}$ and the endemicity of malaria has not been formally tested. Early studies investigating the association 
between $\mathrm{HbC}$ and clinical protection were either inconclusive (Thompson 1962, 1963; Gilles et al. 1967; Guinet et al. 1997) or suggested only a marginal effect of $\mathrm{HbC}$ in comparison to the marked protection afforded by HbS (Ringelhann et al. 1976). This was confirmed most recently in both a large cross-sectional survey (Danquah et al. 2010) and in a birth cohort study (Kreuels et al. 2010), both conducted among children living in areas of high malaria transmission in Ghana. This may well be explained by more recent studies suggesting that protection might be specific to particular categories of strictly defined severe malaria (May et al. 2007) and that it is greater in homozygotes (with HbCC) than in heterozygotes (with $\mathrm{HbAC}$ ) (Agarwal et al. 2000; Modiano et al. 2001; Mockenhaupt et al. 2004a). The strongest evidence for a homozygous advantage of $\mathrm{HbC}$ comes from a large case-control study conducted by Modiano and colleagues in Burkino Faso, in which they found a $29 \%$ reduction in the risk of clinical malaria among children with $\mathrm{HbAC}$ compared to a $93 \%$ reduction among children with HbCC (Modiano et al. 2001). Finally, like HbS, it appears that $\mathrm{HbC}$ has a marked effect on the transmissibility of malaria by the Anopheles vector (Gouagna et al. 2010).

Mechanistically, similar hypotheses have been pursued for $\mathrm{HbC}$ as for $\mathrm{HbS}$. As for $\mathrm{HbAS}$, early studies suggested that the protective effect of $\mathrm{HbC}$ might result from a reduced ability of $P$. falciparum parasites to grow and multiply in red blood cells containing $\mathrm{HbC}$ (Friedman et al. 1979; Pasvol and Wilson 1982; Olson and Nagel 1986; Fairhurst et al. 2003). Subsequently, however, it has been suggested that the mechanism might involve an immunological component (Ringelhann et al. 1976). This is supported by the finding of higher immune responses to PfEMP1 and various malaria antigens among children expressing the HbC allele in a low transmission urban area of Burkina Faso (Verra et al. 2007b), although no differences were found in a higher transmission rural population in the same study or in a more recent study conducted in Mali (Tan et al. 2011). As for HbAS, an alternative hypothesis has recently been developed: that $\mathrm{HbC}$ exerts its protection through a specific effect on cytoadherence, mediated by the altered display of surface-expressed parasite proteins (Fairhurst et al. 2005; Brittain et al. 2007; Cyrklaff et al. 2011).

\section{Hemoglobin E}

Much less is known about the effects of $\mathrm{HbE}$ on malaria than for the other common structural variants of hemoglobin. Like most of the other disorders, $\mathrm{HbE}$ is restricted to populations that have traditionally been endemic for malaria and there is some evidence for a correlation between the prevalence of the two conditions (Flatz et al. 1965; Kar et al. 1992; Win et al. 2005). Moreover, in one Thai population, it has recently been estimated on the basis of genetic linkage analysis that the most frequent variant, $\mathrm{HbE} \beta 26 \mathrm{Glu} \rightarrow$ lys, has reached its current frequency in $<5000$ years, a period compatible with the malaria hypothesis (Ohashi et al. 2004). Nevertheless, few clinical studies have reported the relative risk of clinical malaria in subjects with $\mathrm{HbE}$. In one such study, conducted in adults with malaria who were admitted to the hospital in Thailand, the manifestations of malaria were less severe in patients with $\mathrm{HbE}$ trait (HbAE) (Chotivanich et al. 2002). However, in a similar study, Oo and colleagues found no significant relationship between either HbAE or HbEE and the severity of malaria in adults admitted to the hospital in Burma (Oo et al. 1995). Similarly, a small recent study found no relationship between $\mathrm{HbE}$ and the risk of cerebral malaria in Thai adults (Naka et al. 2008). To the best of our knowledge, the relative risk of malaria in such subjects has not been reported through casecontrol or cohort studies, although a single report from Sri Lanka found subjects with the clinically significant condition $\mathrm{HbE} / \beta$ thalassemia to be at greater risk than normals from $P$. vivax malaria. This observation, which may be explained by the rapid turnover of red cells seen in patients with this condition-as $P$. vivax favors the youngest, most metabolically active red blood cells-suggests that patients with $\mathrm{HbE} / \beta$ thalassemia should be actively protected from malaria (O’Donnell et al. 2009).

Very few studies have examined the potential mechanisms by which $\mathrm{HbE}$ might confer 
malaria protection. In one such study, Chotivanich et al. (2002) found that compared to normal subjects, a smaller proportion of red cells from subjects with $\mathrm{HbAE}$ were susceptible to invasion by $P$. falciparum parasites in culture, raising the possibility that $\mathrm{HbAE}$ might protect against severe malaria by limiting the ability of infections to achieve high parasite densities. The degree to which $\mathrm{HbE}$ protects against different forms of malaria and any potential mechanisms remain, therefore, a subject for further investigation.

\section{THE THALASSEMIAS}

There is strong evidence from population data that malaria selection explains the current distribution of the thalassemias. First, at a global scale, both $\alpha$ and $\beta$ thalassemia follow remarkably similar distribution to that of malaria (Livingstone 1973, 1985; Cavalli-Sforza et al. 1994), an observation that also holds true at a microepidemiological scale. For example, in early studies, Siniscalco and colleagues noted a strong correlation between the population prevalence of $\beta$ thalassemia and the historic incidence of malaria among villages in Sardinia in southern Italy (Siniscalco et al. 1961), whereas Hill and colleagues drew similar conclusions in Melanesia (Hill et al. 1988). Similar observations have subsequently been made regarding the distribution of $\alpha$ thalassemia in South Asia (Modiano et al. 1991), Tanzania (Enevold et al. 2007), and the Pacific (Flint et al. 1986), where in some populations these conditions have virtually reached fixation (Flint et al. 1998). Second, unlike many of the other disorders of hemoglobin, the molecular defects that result in the thalassemias are extremely diverse (see Higgs 2012), having arisen separately and been locally amplified, in multiple populations throughout the malaria-endemic regions of the world. The one notable exception is South America, where in evolutionary terms malaria was introduced only relatively recently.

Despite the overwhelming epidemiological evidence for malaria selection, the protective effect of $\beta$ thalassemia has been the subject of few clinical studies. Nevertheless, in one case-
Epidemiology of the Hemoglobinopathies

control study conducted in northern Liberia, Willcox and colleagues estimated a protective effect of $\sim 50 \%$ (Willcox et al. 1983). Whereas many more studies have recorded, the clinical relationship between $\alpha$ thalassemia and malaria, the results have not been entirely consistent. The incidence of uncomplicated clinical malaria has been lower in $\alpha$ thalassemic than normal subjects in some cohort studies (Wambua et al. 2006; Enevold et al. 2008), whereas in others the incidence has either been equal (Lin et al. 2010; Veenemans et al. 2011) or even higher (Williams et al. 1996; Veenemans et al. 2011). Conversely, studies focused on severe malaria have shown consistent evidence for a strongly protective effect that is generally more marked in homozygous than heterozygous subjects (Allen et al. 1997; Mockenhaupt et al. 2004b; Williams et al. 2005d; Wambua et al. 2006; May et al. 2007). Available data, therefore, provide good evidence for a protective effect of $\alpha$ thalassemia against severe and fatal malaria, but the data on uncomplicated malaria are somewhat perplexing. It seems likely that these observations are pointing to important clues about the mechanism by which $\alpha$ thalassemia protects against severe malaria.

Several studies suggest that, as opposed to protecting against all forms of clinical malaria, $\alpha$ thalassemia might specifically protect against the anemia that commonly complicates infections caused by $P$. falciparum malaria (Allen et al. 1997; Williams et al. 2005d; Wambua et al. 2006; May et al. 2007). Furthermore, unlike $\mathrm{HbAS}$, there is little evidence that $\alpha$ thalassemia has any effect at the level of malaria parasite density (Allen et al. 1997; Mockenhaupt et al. 2004b; Migot-Nabias et al. 2006; Wambua et al. 2006; Enevold et al. 2008; Veenemans et al. 2008, 2011). Such clinical observations suggest that the mechanisms by which $\alpha$ thalassemia protects against malaria might well be different from those involved in HbAS. Two possible explanations for a specific effect against malariainduced anemia have been put forward: first, that the higher red cell counts that are associated with $\alpha$ thalassemia may buffer against the development of anemia during $P$. falciparum infections (Fowkes et al. 2008), and second, that this 
T.N. Williams and D.J. Weatherall

protection might be im-munologically mediated (Veenemans et al. 2008). With regard to the latter, Veenemans and colleagues found that in two cohorts of children in East Africa, the greatest falls in hemoglobin occurred when malaria parasitemia was associated with inflammation in the form of a raise $\mathrm{C}$-reactive protein concentration in blood and that $\alpha$ thalassemia was strongly protective against this "inflammatory" form of the disease (Veenemans et al. 2008). A further characteristic of $\alpha$-thalassemic red blood cells may provide an alternative explanation. In studies conducted in Papua New Guinea, Cockburn and colleagues noted that the expression of complement receptor-1 (CR1) is reduced on the surface of $\alpha$-thalassemic red blood cells (Cockburn et al. 2004). CR1 is a ligand for rosetting in which uninfected red blood cells adhere to parasite-infected red cells in vitro (Figs. 3 and 4). Because rosetting has been associated with severe forms of malaria, including severe anemia, the reduced expression of CR1 might be relevant in the protection afforded by $\alpha$ thalassemia. Finally, it is also possible that immune factors might be involved. In two clinical studies, the incidence of uncomplicated clinical malaria has been paradoxically higher in the youngest $\alpha$-thalassemic children (Williams et al. 1996; Veenemans et al. 2011), raising the possibility that $\alpha$ thalassemia might

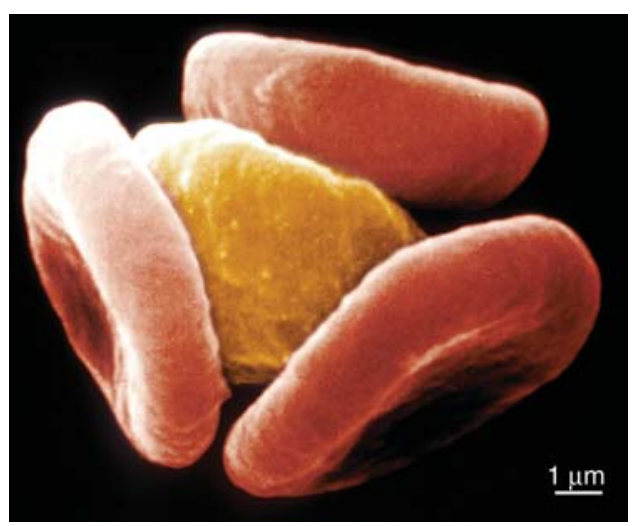

Figure 3. Three-dimensional photograph of normal red cells aggregating around a malaria-infected red cell to form a rosette. (Image supplied by D.J.P. Ferguson, Oxford University.)

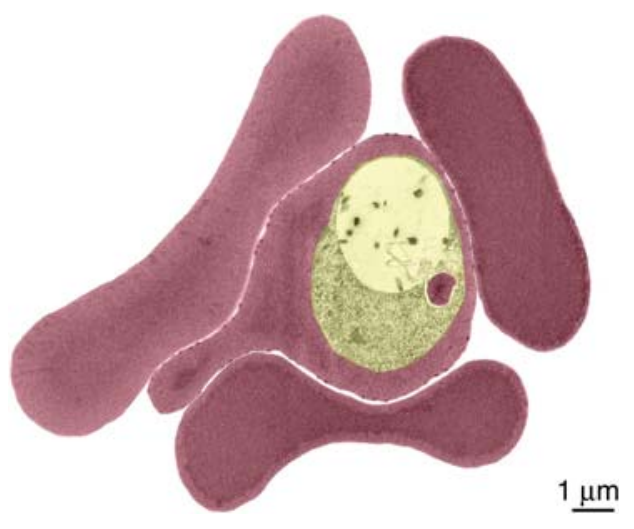

Figure 4. A cross-sectional photograph of a rosette as shown in Figure 3. (Image supplied by D.J.P. Ferguson, Oxford University.)

be acting like a natural vaccine, boosting exposure and immunity to malaria during early childhood. As for all the hemoglobin disorders, the story is more complicated than one might have thought at one point.

\section{EPISTATIC INTERACTIONS BETWEEN THE HEMOGLOBIN DISORDERS}

If, as discussed above, malaria is responsible for the Mendelian selection of many of the inherited disorders of hemoglobin, a question remains about why they have not all become common throughout the whole of the malaria-endemic world. This is a question that has been asked particularly from the perspective of pairs of hemoglobin disorders by a number of different investigators. Studies conducted both in Kenya and in Ghana have recently shown that when inherited alone, both $\mathrm{HbAS}$ and $\alpha$ thalassemia are strongly protective against $P$. falciparum malaria but that the protective effects of each are lost when both conditions are inherited together (Williams et al. 2005c; May et al. 2007). From the perspective of $\mathrm{HbAS}$, this may be explained by the changes in the intracellular concentration of HbAS that accompany the coinheritance of $\alpha$ thalassemia (Brittenham et al. 1980). This negative interaction between the two malariaprotective phenotypes could well explain why both are held at intermediate frequencies in 
populations where both occur together (Williams et al. 2005c; Hedrick 2011; Penman et al. 2011). A similar hypothesis has more recently been advanced to explain the relative frequencies of HbAS and the $\alpha$ and $\beta$ thalassaemias within the Mediterranean region (Penman et al. 2009).

\section{CONCLUSION}

There is no doubt that Haldane's "malaria hypothesis" has been fully vindicated over the years, although his suggested mechanisms for malaria protection in thalassemia carriers, that is, the small size of their red cells, has not stood the test of time. Further work is still required toward a better understanding of the protective mechanisms, information which is of potential value not just in the field of evolutionary biology but also for its potential in directing approaches for the better prevention and management of the different forms of malaria. Similarly, further work on the remarkable epistatic interactions between various malaria-protective polymorphisms should provide invaluable information about the mechanisms for the distribution of the different forms of inherited hemoglobin disorders, in particular high-frequency populations.

\section{ACKNOWLEDGMENTS}

We are extremely grateful to Liz Rose for her help in the preparation of this manuscript. We also thank D.J.P. Ferguson of Oxford University for supplying the photographs shown in Figures 3 and 4.

\section{REFERENCES}

* Reference is also in this collection.

Abu-Zeid YA, Theander TG, Abdulhadi NH, Hviid L, Saeed BO, Jepsen S, Jensen JB, Bayoumi RA. 1992. Modulation of the cellular immune response during Plasmodium falciparum infections in sickle cell trait individuals. Clin Exp Immunol 88: 112-118.

Agarwal A, Guindo A, Cissoko Y, Taylor JG, Coulibaly D, Kone A, Kayentao K, Djimde A, Plowe CV, Doumbo O, et al. 2000. Hemoglobin C associated with protection from severe malaria in the Dogon of Mali, a West African population with a low prevalence of hemoglobin S. Blood 96: $2358-2363$.
Aidoo M, Terlouw DJ, Kolczak MS, McElroy PD, ter Kuile FO, Kariuki S, Nahlen BL, Lal AA, Udhayakumar V. 2002. Protective effects of the sickle cell gene against malaria morbidity and mortality. Lancet 359: 1311-1312.

Allen SJ, O’Donnell A, Alexander ND, Alpers MP, Peto TE, Clegg JB, Weatherall DJ. 1997. $\alpha^{+}$-Thalassemia protects children against disease caused by other infections as well as malaria. Proc Natl Acad Sci 94: 14736-14741.

Allison AC. 1954a. The distribution of the sickle-cell trait in East Africa and elsewhere, and its apparent relationship to the incidence of subtertian malaria. Trans $R$ Soc Trop Med Hyg 48: 312-318.

Allison AC. 1954b. Notes on sickle-cell polymorphism. Ann Hum Genet 19: 39-51.

Allison AC. 1954c. Protection afforded by sickle cell trait against subtertian malarial infection. $\mathrm{Br} \mathrm{Med} J$ 1: 290295.

Ayi K, Turrini F, Piga A, Arese P. 2004. Enhanced phagocytosis of ring-parasitized mutant erythrocytes. A common mechanism that may explain protection against falciparum-malaria in sickle-trait and $\beta$-thalassemia-trait. Blood 104: 3364-3371.

Bayoumi RA, Abu-Zeid YA, Abdulhadi NH, Saeed BO, Theander TG, Hviid L, Ghalib HW, Nugud AH, Jepsen S, Jensen JB. 1990. Cell-mediated immune responses to Plasmodium falciparum purified soluble antigens in sickle-cell trait subjects. Immunol Lett 25: 243-249.

Beet EA. 1946. Sickle cell disease in the Balovale District of Northern Rhodesia. East Afr Med J 23: 75-86.

Beet EA. 1947. Sickle cell disease in northern Rhodesia. East Afr Med J 24: 212-222.

Brain P. 1952. Sickle-cell anaemia in Africa. Br Med J 2: 880.

Brittain NJ, Erexson C, Faucette L, Ward J, Fujioka H, Wellems TE, Fairhurst RM. 2007. Non-opsonising aggregates of IgG and complement in haemoglobin C erythrocytes. Br J Haematol 136: 491-500.

Brittenham G, Lozoff B, Harris JW, Kan YW, Dozy AM, Nayudu NV. 1980. $\alpha$ globin gene number: Population and restriction endonuclease studies. Blood 55: 706-709.

Cabrera G, Cot M, Migot-Nabias F, Kremsner PG, Deloron P, Luty AJ. 2005. The sickle cell trait is associated with enhanced immunoglobulin $G$ antibody responses to Plasmodium falciparum variant surface antigens. J Infect Dis 191: 1631-1638.

Carlson J, Nash GB, Gabutti V, al-Yaman F, Wahlgren M. 1994. Natural protection against severe Plasmodium falciparum malaria due to impaired rosette formation. Blood 84: 3909-3914.

Cavalli-Sforza LL, Menozzi P, Piazza A. 1994. The history and geography of human genes. Princeton University Press, Princeton, NJ.

Cholera R, Brittain NJ, Gillrie MR, Lopera-Mesa TM, Diakite SA, Arie T, Krause MA, Guindo A, Tubman A, Fujioka H, et al. 2008. Impaired cytoadherence of Plasmodium falciparum-infected erythrocytes containing sickle hemoglobin. Proc Natl Acad Sci 105: 991-996.

Chotivanich K, Udomsangpetch R, Pattanapanyasat K, Chierakul W, Simpson J, Looareesuwan S, White N. 2002. Hemoglobin E: A balanced polymorphism protective against high parasitemias and thus severe $P$ falciparum malaria. Blood 100: 1172-1176. 
T.N. Williams and D.J. Weatherall

Christianson A, Howson CP, Modell B. 2006. March of Dimes global report on birth defects. March of Dimes Birth Defects Foundation, New York.

Cockburn IA, Mackinnon MJ, O'Donnell A, Allen SJ, Moulds JM, Baisor M, Bockarie M, Reeder JC, Rowe JA. 2004. A human complement receptor 1 polymorphism that reduces Plasmodium falciparum rosetting confers protection against severe malaria. Proc Natl Acad Sci 101: 272-277.

Cornille-Brogger R, Fleming AF, Kagan I, Matsushima T, Molineaux L. 1979. Abnormal haemoglobins in the Sudan savanna of Nigeria. II: Immunological response to malaria in normals and subjects with sickle cell trait. Ann Trop Med Parasitol 73: 173-183.

Cyrklaff M, Sanchez CP, Kilian N, Bisseye C, Simpore J, Frischknecht F, Lanzer M. 2011. Hemoglobins S and C interfere with actin remodeling in Plasmodium falciparum-infected erythrocytes. Science 334: 1283-1286.

Danquah I, Ziniel P, Eggelte TA, Ehrhardt S, Mockenhaupt FP. 2010. Influence of haemoglobins $S$ and C on predominantly asymptomatic Plasmodium infections in northern Ghana. Trans R Soc Trop Med Hyg 104: 713-719.

Edozien JC, Boyo AE, Morley DC. 1960. The relationship of serum $\gamma$-globulin concentration to malaria and sickling. J Clin Pathol J 13: 118-123.

Eeckels R, Gatti F, Renoirte AM. 1967. Abnormal distribution of haemoglobin genotypes in Negro children with severe bacterial infections. Nature 216: 382 .

Enevold A, Alifrangis M, Sanchez JJ, Carneiro I, Roper C, Borsting C, Lusingu J, Vestergaard LS, Lemnge MM, Morling N, et al. 2007. Associations between $\alpha^{+}$-thalassemia and Plasmodium falciparum malarial infection in northeastern Tanzania. J Infect Dis 196: 451-459.

Enevold A, Lusingu JP, Mmbando B, Alifrangis M, Lemnge MM, Bygbjerg IC, Theander TG, Vestergaard LS. 2008. Reduced risk of uncomplicated malaria episodes in children with $\alpha^{+}$-thalassemia in northeastern Tanzania. Am J Trop Med Hyg 78: 714-720.

Fairhurst RM, Fujioka H, Hayton K, Collins KF, Wellems TE. 2003. Aberrant development of Plasmodium falciparum in hemoglobin CC red cells: Implications for the malaria protective effect of the homozygous state. Blood 101: 3309-3315.

Fairhurst RM, Baruch DI, Brittain NJ, Ostera GR, Wallach JS, Hoang HL, Hayton K, Guindo A, Makobongo MO, Schwartz OM, et al. 2005. Abnormal display of PfEMP-1 on erythrocytes carrying haemoglobin $\mathrm{C}$ may protect against malaria. Nature 435: 1117-1121.

Ferreira A, Marguti I, Bechmann I, Jeney V, Chora A, Palha NR, Rebelo S, Henri A, Beuzard Y, Soares MP. 2011. Sickle hemoglobin confers tolerance to Plasmodium infection. Cell 145: 398-409.

Flatz G, Pik C, Sringam S. 1965. Haemoglobin E and $\beta$ thalassaemia: Their distribution in Thailand. Ann Hum Genet 29: 151-170.

Flint J, Hill AV, Bowden DK, Oppenheimer SJ, Sill PR, Serjeantson SW, Bana-Koiri J, Bhatia K, Alpers MP, Boyce AJ, et al. 1986. High frequencies of $\alpha$-thalassaemia are the result of natural selection by malaria. Nature 321: $744-750$.
Flint J, Harding RM, Boyce AJ, Clegg JB. 1998. The population genetics of the haemoglobinopathies. Baillieres Clin Haematol 11: 1-51.

Fowkes FJ, Allen SJ, Allen A, Alpers MP, Weatherall DJ, Day KP. 2008. Increased microerythrocyte count in homozygous $\alpha^{+}$-thalassaemia contributes to protection against severe malarial anaemia. PLoS Med 5: e56.

Foy H, Kondi A, Rebello A, Martins F. 1952. The distribution of sickle cell trait and the incidence of sickle cell anaemia in the Negro tribes of Portuguese East Africa. East Afr Med J 29: 247-251.

Foy H, Kondi A, Timms GL, Brass W, Bushra F. 1954. The variability of sickle-cell rates in the tribes of Kenya and the Southern Sudan. Br Med J 1: 294-297.

Friedman MJ. 1978. Erythrocytic mechanism of sickle cell resistance to malaria. Proc Natl Acad Sci 75: 1994-1997.

Friedman MJ, Roth EF, Nagel RL, Trager W. 1979. The role of hemoglobins $\mathrm{C}, \mathrm{S}$, and Nbalt in the inhibition of malaria parasite development in vitro. Am J Trop Med Hyg 28: 777-780.

* Fucharoen S, Weatherall DJ. 2012. The hemoglobin E thalassemias. Cold Spring Harb Perspect Med doi: 10.1101/ cshperspect.a011734.

Gilles HM, Fletcher KA, Hendrickse RG, Lindner R, Reddy S, Allan N. 1967. Glucose-6-phosphate-dehydrogenase deficiency, sickling, and malaria in African children in South Western Nigeria. Lancet 1: 138-140.

Gouagna LC, Bancone G, Yao F, Yameogo B, Dabire KR, Costantini C, Simpore J, Ouedraogo JB, Modiano D. 2010. Genetic variation in human HBB is associated with Plasmodium falciparum transmission. Nat Genet 42: $328-331$.

Guggenmoos-Holzmann I, Bienzle U, Luzzatto L. 1981 Plasmodium falciparum malaria and human red cells. II: Red cell genetic traits and resistance against malaria. Int J Epidemiol 10: 16-22.

Guinet F, Diallo DA, Minta D, Dicko A, Sissoko MS, Keita MM, Wellems TE, Doumbo O. 1997. A comparison of the incidence of severe malaria in Malian children with normal and C-trait hemoglobin profiles. Acta Trop 68: $175-182$.

Haldane JBS. 1949. The rate of mutation of human genes. Hereditas 35: 267-273.

Hedrick PW. 2011. Selection and mutation for $\alpha$ thalassemia in nonmalarial and malarial environments. Ann Hum Genet 75: 468-474.

* Higgs DR. 2012. Molecular basis of $\alpha$ thalassemia. Cold Spring Harb Perspect Med doi: 10.1101/cshperspect .a011718.

Hill AV, Bowden DK, O'Shaughnessy DF, Weatherall DJ, Clegg JB. 1988. $\beta$ Thalassemia in Melanesia: Association with malaria and characterization of a common variant (IVS-1 nt 5 G----C). Blood 72: 9-14.

Jallow M, Teo YY, Small KS, Rockett KA, Deloukas P, Clark TG, Kivinen K, Bojang KA, Conway DJ, Pinder M, et al. 2009. Genome-wide and fine-resolution association analysis of malaria in West Africa. Nat Genet 41: $657-665$.

Kaminsky R, Kruger N, Hempelmann E, Bommer W. 1986. Reduced development of Plasmodium falciparum in $\beta$ thalassaemic erythrocytes. Z Parasitenkd 72: 553-556. 
Kar S, Seth S, Seth PK. 1992. Prevalence of malaria in Ao Nagas and its association with G6PD and HbE. Hum Biol 64: $187-197$.

Kreuels B, Kreuzberg C, Kobbe R, Ayim-Akonor M, ApiahThompson P, Thompson B, Ehmen C, Adjei S, Langefeld I, Adjei O, et al. 2010. Differing effects of $\mathrm{HbS}$ and $\mathrm{HbC}$ traits on uncomplicated falciparum malaria, anemia, and child growth. Blood 115: 4551-4558.

Kulozik AE, Wainscoat JS, Serjeant GR, Kar BC, Al-Awamy B, Essan GJF, Falusi AG, Haque SK, Hilali AM, Kate S, et al. 1986. Geographical survey of $\beta^{\mathrm{s}}$-globin gene haplotypes: Evidence for an independent Asian origin of the sickle-cell mutation. Am J Hum Genet 39: 239-244.

Lawaly YR, Sakuntabhai A, Marrama L, Konate L, Phimpraphi W, Sokhna C, Tall A, Sarr FD, Peerapittayamongkol C, Louicharoen C, et al. 2010. Heritability of the human infectious reservoir of malaria parasites. PLOS ONE 5: e11358.

Le Hesran JY, Personne I, Personne P, Fievet N, Dubois B, Beyeme M, Boudin C, Cot M, Deloron P. 1999. Longitudinal study of Plasmodium falciparum infection and immune responses in infants with or without the sickle cell trait. Int J Epidemiol 28: 793-798.

Lin E, Tavul L, Michon P, Richards JS, Dabod E, Beeson JG, King CL, Zimmerman PA, Mueller I. 2010. Minimal as sociation of common red blood cell polymorphisms with Plasmodium falciparum infection and uncomplicated malaria in Papua New Guinean school children. Am J Trop Med Hyg 83: 828-833.

Livingstone FB. 1973. Data on the abnormal hemoglobin and glucose-6-phosphate dehydrogenase deficiency in human populations. Museum of Anthropology, University of Michigan, Ann Arbor, MI.

Livingstone FB. 1985. Frequencies of hemoglobin variants. Oxford University Press, New York.

Luzzatto L, Nwachuku-Jarrett ES, Reddy S. 1970. Increased sickling of parasitised erythrocytes as mechanism of resistance against malaria in the sickle-cell trait. Lancet $\mathbf{1}$ : 319-321.

Makani J, Komba AN, Cox SE, Oruo J, Mwamtemi K, Kitundu J, Magesa P, Rwezaula S, Meda E, Mgaya J, et al. 2010. Malaria in patients with sickle cell anemia: Burden, risk factors, and outcome at the outpatient clinic and during hospitalization. Blood 115: 215-220.

Marsh K, Otoo L, Hayes RJ, Carson DC, Greenwood BM. 1989. Antibodies to blood stage antigens of Plasmodium falciparum in rural Gambians and their relation to protection against infection. Trans R Soc Trop Med Hyg 83: 293-303.

May J, Evans JA, Timmann C, Ehmen C, Busch W, Thye T, Agbenyega T, Horstmann RD. 2007. Hemoglobin variants and disease manifestations in severe falciparum malaria. JAMA 297: 2220-2226.

McAuley CF, Webb C, Makani J, Macharia A, Uyoga S, Opi DH, Ndila C, Ngatia A, Scott JA, Marsh K, et al. 2010 High mortality from Plasmodium falciparum malaria in children living with sickle cell anemia on the coast of Kenya. Blood 116: 1663-1668.

Migot-Nabias F, Pelleau S, Watier L, Guitard J, Toly C, De Araujo C, Ngom MI, Chevillard C, Gaye O, Garcia A. 2006. Red blood cell polymorphisms in relation to Plas-
Epidemiology of the Hemoglobinopathies

modium falciparum asymptomatic parasite densities and morbidity in Senegal. Microbes Infect 8: 2352-2358.

Mockenhaupt FP, Ehrhardt S, Cramer JP, Otchwemah RN, Anemana SD, Goltz K, Mylius F, Dietz E, Eggelte TA, Bienzle U. 2004a. Hemoglobin C and resistance to severe malaria in Ghanaian children. J Infect Dis 190: 10061009.

Mockenhaupt FP, Ehrhardt S, Gellert S, Otchwemah RN, Dietz E, Anemana SD, Bienzle U. 2004b. $\alpha^{+}$Thalassemia protects African children from severe malaria. Blood 104: 2003-2006.

Modell B, Darlison M. 2008. Global epidemiology of haemoglobin disorders and derived service indicators. Bull World Health Organ 86: 480-487.

Modiano G, Morpurgo G, Terrenato L, Novelletto A, Di Rienzo A, Colombo B, Purpura M, Mariani M, Santachiara-Benerecetti S, Brega A, et al. 1991. Protection against malaria morbidity: Near-fixation of the $\alpha$-thalassemia gene in a Nepalese population. Am J Hum Genet 48: 390-397.

Modiano D, Luoni G, Sirima BS, Simpore J, Verra F, Konate A, Rastrelli E, Olivieri A, Calissano C, Paganotti GM, et al. 2001. Haemoglobin C protects against clinical Plasmodium falciparum malaria. Nature 414: 305-308.

Naka I, Ohashi J, Nuchnoi P, Hananantachai H, Looareesuwan S, Tokunaga K, Patarapotikul J. 2008. Lack of association of the $\mathrm{HbE}$ variant with protection from cerebral malaria in Thailand. Biochem Genet 46: 708-711.

Odegbemi JO, Williams AI. 1995. Immunoglobulin levels in malaria infected Nigerians with and without abnormal haemoglobin. Afr J Med Med Sci 24: 21-25.

O'Donnell A, Premawardhena A, Arambepola M, Samaranayake R, Allen SJ, Peto TE, Fisher CA, Cook J, Corran PH, Olivieri NF, et al. 2009. Interaction of malaria with a common form of severe thalassemia in an Asian population. Proc Natl Acad Sci 106: 18716-18721.

Ohashi J, Naka I, Patarapotikul J, Hananantachai H, Brittenham G, Looareesuwan S, Clark AG, Tokunaga K. 2004 Extended linkage disequilibrium surrounding the hemoglobin E variant due to malarial selection. Am J Hum Genet 74: 1198-1208.

Olson JA, Nagel RL. 1986. Synchronized cultures of $P$. falciparum in abnormal red cells: The mechanism of the inhibition of growth in HbCC cells. Blood 67: 9971001.

Oo M, Tin S, Marlar T, O’Sullivan WJ. 1995. Genetic red cell disorders and severity of falciparum malaria in Myanmar. Bull World Health Organ 73: 659-665.

O'Shaughnessy DF, Hill AVS, Bowden DK, Weatherall DJ, Clegg JB. 1990. Globin genes in Micronesia: Origins and affinities of Pacific Island peoples. Am J Hum Genet 46: $144-155$.

Pasvol G, Wilson RJ. 1982. The interaction of malaria parasites with red blood cells. Br Med Bull 38: 133-140.

Pasvol G, Weatherall DJ, Wilson RJ. 1978. Cellular mechanism for the protective effect of haemoglobin $S$ against P. falciparum malaria. Nature 274: 701-703.

Penman BS, Pybus OG, Weatherall DJ, Gupta S. 2009. Epistatic interactions between genetic disorders of hemoglobin can explain why the sickle-cell gene is 
T.N. Williams and D.J. Weatherall

uncommon in the Mediterranean. Proc Natl Acad Sci 106: 21242-21246.

Penman BS, Habib S, Kanchan K, Gupta S. 2011. Negative epistasis between $\alpha^{+}$thalassaemia and sickle cell trait can explain interpopulation variation in South Asia. Evolution 65: 3625-3632.

Piel FB, Patil AP, Howes RE, Nyangiri OA, Gething PW, Williams TN, Weatherall DJ, Hay SI. 2010. Global distribution of the sickle cell gene and geographical confirmation of the malaria hypothesis. Nat Commun 1: 104.

Ringelhann B, Hathorn MK, Jilly P, Grant F, Parniczky G. 1976. A new look at the protection of hemoglobin AS and AC genotypes against Plasmodium falciparum infection: A census tract approach. Am J Hum Genet 28: 270-279.

Roth EF Jr, Friedman M, Ueda Y, Tellez I, Trager W, Nage RL. 1978. Sickling rates of human AS red cells infected in vitro with Plasmodium falciparum malaria. Science 202: 650-652.

Scott JA, Berkley JA, Mwangi I, Ochola L, Uyoga S, Macharia A, Ndila C, Lowe BS, Mwarumba S, Bauni E, et al. 2011. Relation between falciparum malaria and bacteraemia in Kenyan children: A population-based, case-control study and a longitudinal study. Lancet 378: 1316-1323.

Senok AC, Li K, Nelson EA, Yu LM, Tian LP, Oppenheimer SJ. 1997. Invasion and growth of Plasmodium falciparum is inhibited in fractionated thalassaemic erythrocytes. Trans R Soc Trop Med Hyg 91: 138-143.

Serjeant GR. 2005. Mortality from sickle cell disease in Africa. BMJ 330: 432-433.

Shear HL, Roth EF Jr, Fabry ME, Costantini FD, Pachnis A, Hood A, Nagel RL. 1993. Transgenic mice expressing human sickle hemoglobin are partially resistant to rodent malaria. Blood 81: 222-226.

Siniscalco M, Bernini L, Latte B. 1961. Favism and thalassaemia in Sardinia and their relationship to malaria. $\mathrm{Na}$ ture 190: 1179-1180.

Storey J, Fleming AF, Cornille-Brogger R, Molineaux L, Matsushima T, Kagan I. 1979. Abnormal haemoglobins in the Sudan savanna of Nigeria. IV: Malaria, immunoglobulins and antimalarial antibodies in haemoglobin AC individuals. Ann Trop Med Parasitol 73: 311-315.

Tan X, Traore B, Kayentao K, Ongoiba A, Doumbo S, Waisberg M, Doumbo OK, Felgner PL, Fairhurst RM, Crompton PD. 2011. Hemoglobin S and C heterozygosity enhances neither the magnitude nor breadth of antibody responses to a diverse array of Plasmodium falciparum antigens. J Infect Dis 204: 1750-1761.

Thompson GR. 1962. Significance of haemoglobins S and C in Ghana. Br Med J 5279: 682-685.

Thompson GR. 1963. Malaria and stress in relation to haemoglobins S and C. Br Med J 5363: 976-978.

Udomsangpetch R, Sueblinvong T, Pattanapanyasat K, Dharmkrong-at A, Kittikalayawong A, Webster HK. 1993. Alteration in cytoadherence and rosetting of Plasmodium falciparum-infected thalassemic red blood cells. Blood 82: 3752-3759.

Veenemans J, Andang'o PE, Mbugi EV, Kraaijenhagen RJ, Mwaniki DL, Mockenhaupt FP, Roewer S, Olomi RM, Shao JF, van der Meer JW, et al. 2008. $\alpha^{+}$-Thalassemia protects against anemia associated with asymptomatic malaria: Evidence from community-based surveys in Tanzania and Kenya. J Infect Dis 198: 401-408.

Veenemans J, Jansen EJ, Baidjoe AY, Mbugi EV, Demir AY, Kraaijenhagen RJ, Savelkoul HF, Verhoef H. 2011. Effect of $\alpha^{+}$-thalassaemia on episodes of fever due to malaria and other causes: A community-based cohort study in Tanzania. Malar J 10: 280.

Verra F, Bancone G, Avellino P, Blot I, Simpore J, Modiano D. 2007a. Haemoglobin C and S in natural selection against Plasmodium falciparum malaria: A plethora or a single shared adaptive mechanism? Parassitologia 49: 209-213.

Verra F, Simpore J, Warimwe GM, Tetteh KK, Howard T, Osier FH, Bancone G, Avellino P, Blot I, Fegan G, et al. 2007b. Haemoglobin $C$ and $S$ role in acquired immunity against Plasmodium falciparum malaria. PLoS ONE 2: e978.

Wambua S, Mwangi TW, Kortok M, Uyoga SM, Macharia AW, Mwacharo JK, Weatherall DJ, Snow RW, Marsh K, Williams TN. 2006. The effect of $\alpha^{+}$-thalassaemia on the incidence of malaria and other diseases in children living on the coast of Kenya. PLoS Med 3: e158.

Weatherall DJ. 2010. Thalassemia as a global health problem: Recent progress towards its control in the developing countries. Ann NY Acad Sci 1202: 17-23.

Weatherall DJ, Clegg JB. 2001. The thalassaemia syndromes. Blackwell Science, Oxford.

Willcox M, Bjorkman A, Brohult J. 1983. Falciparum malaria and $\beta$-thalassaemia trait in northern Liberia. Ann Trop Med Parasitol 77: 335-347.

Williams TN, Obaro SK. 2011. Sickle cell disease and malaria morbidity: A tale with two tails. Trends Parasitol 27: 315-320.

Williams TN, Maitland K, Bennett S, Ganczakowski M, Peto TE, Newbold CI, Bowden DK, Weatherall DJ, Clegg JB. 1996. High incidence of malaria in $\alpha$-thalassaemic children. Nature 383: 522-525.

Williams TN, Mwangi TW, Roberts DJ, Alexander ND, Weatherall DJ, Wambua S, Kortok M, Snow RW, Marsh K. 2005a. An immune basis for malaria protection by the sickle cell trait. PLoS Med 2: e128.

Williams TN, Mwangi TW, Wambua S, Alexander ND, Kortok M, Snow RW, Marsh K. 2005b. Sickle cell trait and the risk of Plasmodium falciparum malaria and other childhood diseases. J Infect Dis 192: 178-186.

Williams TN, Mwangi TW, Wambua S, Peto TEA, Weatherall DJ, Gupta S, Recker M, Penman BS, Uyoga S, Macharia A, et al. 2005c. Negative epistasis between the malaria-protective effects of $\alpha^{+}$-thalassemia and the sickle cell trait. Nat Genet 37: 1253-1257.

Williams TN, Wambua S, Uyoga S, Macharia A, Mwacharo JK, Newton CR, Maitland K. 2005d. Both heterozygous and homozygous $\alpha^{+}$thalassemias protect against severe and fatal Plasmodium falciparum malaria on the coast of Kenya. Blood 106: 368-371.

Win N, Lwin AA, Oo MM, Aye KS, Soe S, Okada S. 2005. Hemoglobin E prevalence in malaria-endemic villages in Myanmar. Acta Med Okayama 59: 63-66. 


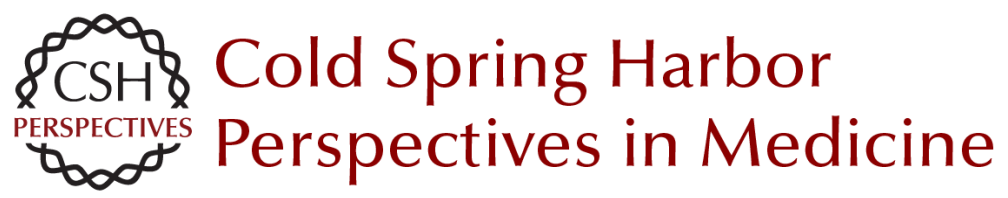

\section{World Distribution, Population Genetics, and Health Burden of the Hemoglobinopathies}

Thomas N. Williams and David J. Weatherall

Cold Spring Harb Perspect Med 2012; doi: 10.1101/cshperspect.a011692

Subject Collection Hemoglobin and Its Diseases

The Natural History of Sickle Cell Disease

Graham R. Serjeant

Current Management of Sickle Cell Anemia Patrick T. McGann, Alecia C. Nero and Russell E. Ware

Cell-Free Hemoglobin and Its Scavenger Proteins: New Disease Models Leading the Way to Targeted Therapies

Dominik J. Schaer and Paul W. Buehler

Clinical Manifestations of $\alpha$-Thalassemia Elliott P. Vichinsky

Erythroid Heme Biosynthesis and Its Disorders Harry A. Dailey and Peter N. Meissner

Hemoglobin Variants: Biochemical Properties and

Clinical Correlates

Christopher S. Thom, Claire F. Dickson, David A. Gell, et al.

The Prevention of Thalassemia Antonio Cao and Yuet Wai Kan

The Switch from Fetal to Adult Hemoglobin Vijay G. Sankaran and Stuart H. Orkin

Transcriptional Mechanisms Underlying

Hemoglobin Synthesis

Koichi R. Katsumura, Andrew W. DeVilbiss, Nathaniel J. Pope, et al.

Iron Deficiency Anemia: A Common and Curable Disease Jeffery L. Miller

Management of the Thalassemias Nancy F. Olivieri and Gary M. Brittenham

The Molecular Basis of $\beta$-Thalassemia Swee Lay Thein

Erythropoiesis: Development and Differentiation Elaine Dzierzak and Sjaak Philipsen

Erythropoietin

H. Franklin Bunn

Classification of the Disorders of Hemoglobin Bernard G. Forget and H. Franklin Bunn

The Molecular Basis of $\alpha$-Thalassemia Douglas R. Higgs

For additional articles in this collection, see http://perspectivesinmedicine.cshlp.org/cgi/collection/ 